(25\%) did not use any tool to monitor their RA. Few patients (16/126, 13\%) used numeric reminders for their treatments. A specific application for RA was used by $27 / 127$ patients (21\%) using eHealth. Age, level of study, employment, treatment, comorbidities, membership of a patient association group and patient education program were associated with the use of eHealth for RA in univariate analysis. In multivariate analysis, membership of patient's association (OR: 5.8 [3.0-11.2]), bDMARDs use (OR: 0.6 [0.4-1]) and comorbidities (OR: 0.7 [0.6$0.81)$ remained associated with eHealth use for RA. According to the patients, recommendation by a doctor $(n=225 / 330,68 \%)$, ease of use $(n=105 / 330,32 \%)$ and data security $(n=69 / 330,21 \%)$ were the factors that would favor the use of eHealth.

Conclusion: To date, few patients used eHealth for their disease. The use of a reliable and validated eHealth tool in RA could therefore be promoted by rheumatologist and might optimize the therapeutic adherence.

References:

[1] Mosa ASM, Yoo I, Sheets L. A systematic review of healthcare applications for smartphones. BMC Med Inform Decis Mak. 10 juill 2012;12:67.

[2] Lorig KR, Ritter PL, Laurent DD, Plant K. The internet-based arthritis self-management program: a one-year randomized trial for patients with arthritis or fibromyalgia. Arthritis Rheum. 15 juill 2008;59(7):1009-17.

[3] Charpentier G, Benhamou P-Y, Dardari D, Clergeot A, Franc S, Schaepelynck-Belicar $P$, et al. The Diabeo software enabling individualized insulin dose adjustments combined with telemedicine support improves

Disclosure of Interests: Marion Magnol: None declared, Eleonore Berard: None declared, Claire Rempenault: None declared, Benjamin Castagne: None declared, marine pugibet: None declared, Cédric Lukas: None declared, Anne Tournadre: None declared, Pascale Vergne-Salle: None declared, Thomas Barnetche: None declared, Marie-Elise Truchetet: None declared, Adeline Ruyssen-Witrand Grant/research support from: Abbvie, Pfizer, Consultant of: Abbvie, BMS, Lilly, Mylan, Novartis, Pfizer, Sandoz, Sanofi-Genzyme

DOI: 10.1136/annrheumdis-2020-eular.2395

\section{THU0582 EFFECTIVE MANAGEMENT OF REFRACTORY GOUT: EFFECT OF ONLINE CONTINUING EDUCATION ON RHEUMATOLOGISTS' KNOWLEDGE}

N. Mehta ${ }^{1}$, S. Fagerlie ${ }^{1}$, J. Maeglin ${ }^{1} .{ }^{1}$ Medscape, New York, United States of America

Background: Gout is a chronic condition with a considerable effect on patient health and quality of life. Despite the availability of multiple pharmacologic treatments and evidence-based management guidelines, treatment targets are often not achieved in patients with gout. Identification and optimal management of patients with severe or refractory gout is specially challenging.

Objectives: The objective of this study was to determine if an online, continuing education activity could improve knowledge of rheumatologists regarding strategies to ensure effective and safe use of urate-lowering therapies in the management of patients with refractory gout.

Methods: Educational design included an online, 30-minute, video-based discussion among two faculty experts with synchronized slides. Educational effectiveness was assessed with a repeated-pairs pre-/post-assessment study design using 3 knowledge questions and 1 confidence question, in which each individual served as his/her own control. A chi-squared test assessed differences from pre- to post-assessment. $P$ values $<.05$ are statistically significant. Cramer's $V$ was used to calculate the effect size $(<0.06$ modest effect; 0.06-0.15 noticeable effect; 0.16-0.26 considerable effect; $>0.26$ extensive effect). The activity launched May 1, 2019, with data collected through December 30, 2019.

Results: The analysis set consisted of responses from rheumatologists $(n=300)$ who answered all assessment questions during the study period. Analysis of pre- vs post-intervention responses demonstrated a significant improvement in overall knowledge of rheumatologists with considerable educational impact $(\mathrm{V}=.201, \mathrm{P}<.001)$. Average correct responses increased from $54 \%$ pre to $74 \%$ post education. Specific areas of improvement in knowledge include:

-Optimal strategies for reducing the risk for immunogenicity associated with the use of pegloticase in patients with refractory gout $(40 \%$ pre, $73 \%$ post; $P<.001 ; \mathrm{V}=.326)$ -Serum uric acid targets to optimize management of the patient with severe or refractory gout (45\% pre, $57 \%$ post; $\mathrm{P}<.05 ; \mathrm{V}=.120$ )

-Selection of pegloticase for rapid decreases in tophi and serum uric acid in patients with refractory gout $(77 \%$ pre, $91 \%$ post; $P<.001 ; \mathrm{V}=.187)$

Post-education, $32 \%$ of rheumatologists were more confident in their ability to manage patients with refractory gout.

Conclusion: This study demonstrated the success of online, 30-minute, video-based discussion among two faculty experts with synchronized slides on improving the knowledge of rheumatologists regarding appropriate management of patients with refractory gout.

Disclosure of Interests: None declared

DOI: 10.1136/annrheumdis-2020-eular.5874

\section{THU0583 STRATEGIES FOR ASSESSMENT OF COMPETENCES DURING RHEUMATOLOGY TRAINING ACROSS EUROPE: RESULTS OF A QUALITATIVE STUDY.}

A. Najm ${ }^{1,2}$, A. Alunno $^{3}$, F. Sivera ${ }^{4,5}$, S. Ramiro ${ }^{6,7}$, C. Haines ${ }^{8}$ on behalf of Working Group for Competences Assessment in Rheumatology. ${ }^{1}$ Nantes University Hospital, Department of Rheumatology, Nantes, France; ${ }^{2}$ University of Medicine Nantes, INSERM UMR 1238, Nantes, France; ${ }^{3}$ University of Perugia, Department of Rheumatology, Perugia, Italy; ${ }^{4}$ Hospital General Universitario Elda, Department of Rheumatology, Elda, Spain; ${ }^{5}$ Universidad Miguel Hernandez, Department of Medicine, Elche, Spain, Spain; ${ }^{6}$ Leiden University Medical Center, Leiden, Department of Rheumatology, Leiden, Netherlands; ${ }^{7}$ Zuyderland Medical Center, Heerlen, Netherlands; ${ }^{8}$ King's College, London, United Kingdom, London, United Kingdom

Background: In order to become a rheumatologist, trainees must successfully complete a rheumatology training program. Both the content and the assessments within these programs are regulated by national authorities, and therefore a wide heterogeneity between countries is expected.

Objectives: To gain insight into current methods and practices for the assessment of competences during rheumatology training, and to explore the underlying priorities and rationales for competence assessment across EULAR countries. Methods: We used a qualitative approach through online focus groups of rheumatology trainers and trainees, separately. The study included five countries Denmark, The Netherlands, Slovenia, Spain and United Kingdom. A summary of current practices of assessment of competences was developed, modified and validated during the focus groups. A prioritising method (9 diamond technique) was then used to identify key assessment priorities.

Results: Overall, 26 participants (12 trainers, 14 trainees), participated in 9 online focus groups (2 per country, except Slovenia), totalling 12 hours of online discussion. Strong nationally (Netherlands, UK) or institutionally (Spain, Slovenia, Denmark) standardised approaches were described. Current practices were described as follows: two countries only provide national summative assessments (Slovenia, UK), while all were providing formative assessments regularly at varying frequencies. All groups identified providing frequent formative feedback to trainees for developmental purposes as the highest priority (figure 1). Most discussions identified a need for improvement, particularly in developing streamlined approaches to portfolios that remain close to clinical practice, protecting time for quality observation and feedback, and adopting systematic approaches to incorporating teamwork and professionalism into assessment systems.

\begin{tabular}{|c|c|c|}
\hline Joint group priority order ( $n=26$ ) & $\begin{array}{l}\text { Trainers priority } \\
\text { order } \\
(n=12)\end{array}$ & $\begin{array}{l}\text { Trainees priority } \\
\text { order }(n=14)\end{array}$ \\
\hline $\begin{array}{l}\text { 1. Getting and giving regular feedback on real life } \\
\text { practice is most important to learning (regular } \\
\text { feedback). }\end{array}$ & 1. regular feedback & 1. regular feedback \\
\hline $\begin{array}{l}\text { 2. As well as service provision, the main priority is } \\
\text { to make sure trainees succeed in their training to } \\
\text { time, to agreed standards (service, timely). }\end{array}$ & 4. portfolio driven & 2. service, timely \\
\hline $\begin{array}{l}\text { 3. Being assessed on conducting effective clinical } \\
\text { examinations across a suitable range of cases is } \\
\text { vital (effective in clinic). }\end{array}$ & 2. service, timely & 3. effective in clinic \\
\hline $\begin{array}{l}\text { 4. A trainee portfolio drives the trainee and trainer } \\
\text { to sample across practice for both } \\
\text { developmental and qualifying purposes } \\
\text { (portfolio driven). }\end{array}$ & 3. effective in clinic & 5. regular skills \\
\hline $\begin{array}{l}\text { 5. Skills such as injections or ultrasound should be } \\
\text { assessed regularly throughout training (regular } \\
\text { skills). }\end{array}$ & $\begin{array}{l}\text { 7. functions in } \\
\text { teams }\end{array}$ & 6. prevent failure \\
\hline $\begin{array}{l}\text { 6. Once trainees get to this stage, every help } \\
\text { should be available to prevent failure (prevent } \\
\text { failure). }\end{array}$ & 5. regular skills & $\begin{array}{l}\text { 7. functions in } \\
\text { teams }\end{array}$ \\
\hline $\begin{array}{l}\text { 7. How a trainee functions in teams is an important } \\
\text { aspect of becoming fit to practice (functions in } \\
\text { teams). }\end{array}$ & 6. prevent failure & 4. portfolio driven \\
\hline $\begin{array}{l}\text { 8. Rigorous rheumatological knowledge tests are } \\
\text { the best way to assess future rheumatologists } \\
\text { (knowledge tests). }\end{array}$ & 8. knowledge tests & 8. knowledge tests \\
\hline $\begin{array}{l}\text { 9. A professional attitude will emerge in time } \\
\text { anyway and is impossible to assess, so best to } \\
\text { leave this alone (professional attitudes emerge). }\end{array}$ & $\begin{array}{l}\text { 9. professional } \\
\text { attitudes emerge }\end{array}$ & $\begin{array}{l}\text { 9. professional } \\
\text { attitudes emerge }\end{array}$ \\
\hline
\end{tabular}

Figure 1. Priorities on assessment of competences for all participants and stratified by trainees and trainers. 